\section{International Scientific Journal Theoretical \& Applied Science}

p-ISSN: 2308-4944 (print) e-ISSN: 2409-0085 (online)

Year: 2015 Issue: 05 Volume: 25
Aiym Ibragim

Master of Humanitarian Sciences, Lecturer Arkalyk State Pedagogical Institute named after I.Altynsarin Arkalyk, Kostanay region, Kazakhstan aiym.ibragim@mail.ru

Published: $30.05 .2015 \quad$ http://T-Science.org

SECTION 29. Literature. Folklore. Translation Studies.

\title{
SOME STRUCTURAL AND GRAMMATICAL FEATURES OF HYDRONYMS OF THE KOSTANAY REGION
}

Abstract: This article discusses some of the structural and grammatical features of hydronyms of Kostanay region of Kazakhstan. Analysis of the material allowed the author to identify the main structural models of word formation of hydronyms. The conclusion is that hydronyms up tokens with different topographic linguistic identity Slavonic $\sim$ Russian and Turkic $\sim$ Kazakh. However, most of them make up a unit Turkic $\sim$ Kazakh origin.

Key words: hydronym, structural and grammatical features, place name, toponym, Kostanay, Kazakhstan.

Language: Russian

Citation: Ibragim A (2015) SOME STRUCTURAL AND GRAMMATICAL FEATURES OF HYDRONYMS OF THE KOSTANAY REGION. ISJ Theoretical \& Applied Science 05 (25): 169-172.

Soi: http://s-o-i.org/1.1/TAS*05(25)32 Doi: crossef http://dx.doi.org/10.15863/TAS.2015.05.25.32

\section{НЕКОТОРЫЕ СТРУКТУРНО-ГРАММАТИЧЕСКИЕ ОСОБЕННОСТИ ГИДРОНИМОВ КОСТАНАЙСКОЙ ОБЛАСТИ}

Аннотация: В статье рассматриваются некоторые структурно-грамматические особенности гидронимов Костанайской области Республики Казахстан. Анализ материала позволил автору определить основные структурные модели образования гидронимов. Делается вывод о том, что гидронимы составляют лексемы с топоосновами различной языковой принадлежности - славянской (русской) $и$ тюркской (казахской). Однако, большую их часть составляют единицы тюркского (казахского) происхождения.

Ключевые слова: гидроним, структурно-грамматическая особенность, топоним, Костанайская область, Республика Казахстан.

Гидронимия - это совокупность названий водных объектов, а гидронимика - отрасль ономастики, изучающая гидронимы. Под гидронимом подразумевается наименование любого водного объекта. Объектом изучения для гидронимики могут быть гидронимы в целом как специфический вид собственных имен, гидронимы определенной территории и отдельные водные названия. Из всех топонимических групп - имен населенных мест, гор, улиц и т.д. - самыми трудными для выяснения этимологий, по мнению исследователя, оказываются названия рек. Они менее подвержены изменениям времени, нередко имеют большой возраст, а потому достаточно непросто восстановить их первичную форму и содержание.

Исследование гидронимии предполагает изучение названия любого водного объекта, в том числе лимнонимов (название озер), потамонимов (название рек, ручьев) [1, с.112].

Всем хорошо известно, что наши предки предпочитали селиться около водоемов. Их жизнедеятельность существовала непосредственно с водой. Иногда названия гидронимов переходили в названия населенных пунктов и наоборот. Общество выбирало себе наиболее благоприятные для проживания места. Размещались возле рек и озер, где можно было держать скот, служивших им источниками пищи. Гидронимы иногда позволяют восстановить древние имена или прозвища людей, не зафиксированные историческими источниками. Давая имя географическому объекту и применяя это имя в речи в процессе коммуникации мы вызываем в сознании образ объекта, соотнося его с определенными пространственными параметрами. Однако у любого географического 
объекта имеются и определенные признаки, свойства, присущие ему и отличающие его от других. Воды Земли - проточные и непроточные, озера и болота, родники и ручьи, реки и моря чрезвычайно разнообразны по своим физикогеографическим, химическим и другим характеристикам. Люди, дававшие наименование водному объекту, осознанно либо невольно выбирали его наиболее бросающиеся в глаза признаки. Подобные наименования, равно как принцип, никак не появлялись беспричинно, они отражали особенности окружающей среды.

Различные физико-географические характеристики рек и озер нашли свое выражение в их названиях. В них раскрываются характерные черты течения реки, цвет и вкус, запах воды, характер русла реки или ее проймы, особенности почвы, наличие тех или иных видов растительности по берегам, видов животных и рыб, обитающих в водоемах либо находящейся вокруг территории.

Рассмотрим грамматические особенности гидронимов Костанайской области Республики Казахстан.

В группе гидронимов наименований рек и озер Костанайской области около 723 наименований $[2,3,4,5]$, закрепленных на современной карте области.

В структурно-грамматические особенности гидронимов Костанайской области рассматриваются их способы образования, проводится структурный анализ, выявляются продуктивные словообразовательные модели, отмечаются топоформанты, которые участвуют в их создании.

Гидронимы составляют лексемы с топоосновами различной языковой принадлежности - славянской (русской) и тюркской (казахской). Однако, большую их часть составляют единицы тюркского (казахского) происхождения - около 685 ед. (94 \%).

Основываясь на местные казахские названия озер, отражающих их особенности и структуру, чаще в наименованиях встречаются словосложения, присоединение таких слов как «коль» или «куль», «копа», «соры», «тузы», «тенгизы (тенизы)» [6, с.21]. Например:

- «коль» или «куль» - озеро (Ногайколь, с каз.яз. «Ноғай»-этноним, «көл» - озеро, т.е. ногайское озеро /Аулиекольский район/ [4, c.127]; Айырколь с каз.яз. «Айыр» - вилы, развилка, «көл» - озеро, т.е. разветвленное озеро /Камыстинский район/ [4, с.152]; Ульлколь с каз.яз. «Ұлы» - большой, главный, «көл» - озеро, т.е. большое главное озеро /Наурзумский район/ [5, c.589]);

- «копа» - солоноватые водоемы с бедной луговой растительностью, более чем на 4/5 занятые тростниковыми зарослями и сплавинами
(Шолаккопа с каз.яз. «Шолақ» - невысокий, «қопа»-заросли, т.е. место невысоких зарослей /Наурзумский район/ [5, с.591]; Близкопа с каз.яз. «Біліс» - знакомое, «қопа» - болотистое озеро, т.е. знакомое болотистое место /Камыстинский район/ [4, с.153]; Коскопа с каз.яз. Қос-пара, «қопа» - болотистое озеро, т.е. парное, болотистое озеро /Денисовский район/ [3, с.105]; Аксакалкопа с каз.яз. «Ақсақал» - старый, уважаемый, «қопа» - болотистое место, т.е. старое болотистое место /Камыстинский район/ $[4$, c.153]);

- «соры» - сильно засоленные мелководные водоемы, наполняющиеся весной и к осени пересыхающие (Токалсор с каз.яз. «Тоқал» младшая жена, «сор»- соленое озеро, т.е. маленькое озеро /Аулиекольский район/ [4, c.129]; Ащзысор с каз.яз. «Ащы» - горькое, «сор»соленое озеро, т.е. озеро, содержащее большое количество соли /Камыстинский район/ [4, с.153]; Тентексор с каз.яз. «Тентек» - буйный, «сор» соленое, буйное озеро /Тарановский район/ [3, c.90]);

- «тузы» - соленые самосадочные озера с преобладанием поваренной соли (Тузколь с каз.яз. «Тұз» - соль, «көл»- озеро, т.е. место, богатое солью /Мендыкаринский район/ [5, 587]; Тузкудык с каз.яз. «Тұз» - соль, «құдық» колодец, т.е. колодец с соленой водой /Жангельдинский район/ [5, с.587]);

- «тенгизы (тенизы)» - озера с большой площадью котловины и водного зеркала, чаще соленые или солоноватые (Тенизколь с каз.яз. «Теңіз» - необъятное море, «көл» - озеро, т.е. озеро, необъятное как море /Камыстинский район/ [4, с.157]).

Казахским топонимическим типом доминирует морфологический способ в его аффиксальной разновидности (-mbl-/-mi-,-лbl-,-blқ-ван-, -бa-,-дbl- $u$ др.). Например: озеро Мияльюзен, от каз.яз. «мия»-солодка, -лы- афф., «өзен» -речка, т.е. речка, где растет солодка /Аулиекольский район/ [4, с.126]; озеро Кайындысор от каз.яз. «қайын» - береза, -дыафф. «сор»- соленое озеро, т.е. озеро, где растут березы /Камыстинский район/ [4, с.154]; река Кумды от каз.яз. құм - песок, -ды- афф. - река с песчаным берегом /Жангельдинский район/ [5, c.570]; река Шортанды от каз.яз. «шортан» щука, -ды- афф., т.е. щучья река /Житикаринский район/ [3, с.128].

Рассматривая русскую языковую принадлежность гидронимов, составляющие около 41 ед. (6\%), имеют следующие особенности. Морфологический анализ показал, что самой распространенной частью речи, используемой для образования топонимов, является имя прилагательное - ок. 27 ед. (65\%): река Черная (Карабалыкский район) [5, с.590], 
озеро Белокаменное (Карабалыкский район) [2, с.82], озеро Речное (Узункольский район) [5, c.579].

Малочисленны группы существительных, участвующие в топообразовании (12 ед., 29\%), представлены в основном именами собственными - личными именами, фамилиями и прозвищами (6 ед., $14 \%$ ): озеро Терехово (Костанайский район) [2, с.153], озеро Саратов (Костанайский район) [5, с.580], озеро Попов (Наурзумский район) $[5$, с.581]. Также малочисленна группа топонимов, образованных от нарицательных существительных (5 ед., 12\%): озеро Сирень (Карабалыкский район) [5, с.582], озеро Котлован (Денисовский район) [5, с.569]. В рассматриваемых русских наименованиях, числительное, как часть речи, представлено единично, например, озеро Tретье (Аулиекольский район).

Рассмотрение компонентного состава гидронимов двух языковых принадлежностей свидетельствует о том, что большую часть представляют однословные номинации - 663 единиц, или $91 \%$ всех исследованных гидронимов. Они подразделяются на:

- однокорневые (23 ед., 3 \%): река Уй (Карабалыкский район) [2, с.87], озеро Сор (Федоровский район) [2, с.121], озеро Сур (Федоровский район) [2, с.121];

- производные (219 ед., 33 \%): река Жыланды (Житикаринский район) [3, с.127], озеро Учительское (Аулиекольский район) [4, c.129], озеро Камышное (Узункольский район) [5, c.561], река Шортанды (Житикаринский район) [3, с.128]; сложные (421 ед., 63\%): река Анызбутак (Житикаринский район) [3, с.126], озеро Жекеколь (Амангельдинский район) [5, c.557].
Составные топонимы представлены двухсловными и трехсловными единицами (50 ед., 7\%): река Capbl Тургай (Амангельдинский район) [5, с.580], река Улькен Дамды (Наурзумский район) [4, с.171], река Улькен Сабасаль-Тургай (Амангельдинский район) [5, c.588]. В нашем фактическом материале они единичны, что связано с главным «законом» топонимики - название должно быть простым и легко запоминающимся.

Из этого следует, что гидронимы содействуют расширению ономастической лексики, т. е. сферы собственных имен. В языке происходит неизменный и функциональный процесс образования новейших слов от географических названий. В итоге обогащается лексика нашего языка. От гидронимов образуются почти все наименования населенных мест и улиц, имена и фамилии людей, клички животных и т.д. [7, 8]. Водные объекты на начальной стадии развития любой цивилизации играли главную роль, конкретно по рекам происходило поселение этнических групп. Данные гидронимии (так как они наиболее древние и устойчивые) разрешают определить этнолингвистическую карту прошлого. С помощью гидронимов возможно объяснить возникновение названий почти всех географических объектов [9]. Многослойность топонимов в пределах какой-нибудь местности может указывать об их разной языковой принадлежности, что позволяет определить былые миграции народов [10].

Анализ способов образования гидронимов Костанайской области позволил определить, что морфологический способ топообразования географических наименований данного региона основывается на развитой системе аффиксального словопроизводства.

\section{References:}

1. Subbotina TV (2011) Lokus, topos, urbonim, mikrotoponim: $\mathrm{k}$ voprosu o soderzhanii prostranstvennykh ponyatiy // Vestnik Chelyabinskogo gosudarstvennogo universiteta. 2011. № $24 \quad$ (239). Filologiya. Iskusstvovedenie. Vyp. 57. -pp. 111-113.

2. Abil' EA, etc. (2010) Istoricheskaya toponimika Kostanayskoy oblasti. V 5-ti chastyakh. Nauchnoe izdanie. Chast' 2 (Karabalykskiy, Fedorovskiy, Kostanayskiy rayony). Kostanay: TOO «Tsentrum», 2010. - 294 p.
3. Kuzembayuly A, etc. (2010) Istoricheskaya toponimika Kostanayskoy oblasti. V 5-ti chastyakh. Nauchnoe izdanie. Chast' 3 (Taranovskiy, Denisovskiy i Zhitikarinskiy rayony). - Kostanay: TOO «Tsentrum», 2010. $260 \mathrm{p}$.

4. Kuzembayuly A, etc. (2012) Istoricheskaya toponimika Kostanayskoy oblasti. V 5-ti chastyakh. Nauchnoe izdanie. Chast' 4 (Auliekol'skiy, Kamystinskiy, Naurzumskiy rayony). - Kostanay: TOO «Tsentrum», 2012.$300 \mathrm{p}$. 
5. (2010) Toponimika. Entsiklopedicheskiy spravochnik. - Almaty: TOO «Aruna Ltd.», 2010. -816 p.

6. (2002) Vazhneyshie vodno-bolotnye ugod'ya Severnogo Kazakhstana (v predelakh Kostanayskoy i zapadnoy chasti SeveroKazakhstanskoy oblastey) /Pod red. T.M. Braginoy, E.A. Bragina - M.: Russkiy universitet, 2002.- $156 \mathrm{p}$.

7. Ibragim AE (2014) Leksiko-semanticheskaya osobennosti gidronimov Kostanayskoy oblasti // «Nauka i obrazovanie v usloviyakh globalizatsii: segodnyashnee sostoyanie i perspektivy»: Sb. nauchn. Materialov Respublikanskoy nauchno-prakticheskoy konferentsii, 06 may 2014, Aktobe, KRMU. Aktobe: Dizayn-studiya «Palitra», 2014. -275 p.

8. Ibragim AE (2014) Leksiko-semanticheskiy aspekt godonimov g.Arkalyka Kostanayskoy oblasti (na primere antroponimov) // «Nauka i obrazovanie v usloviyakh globalizatsii: segodnyashnee sostoyanie i perspektivy»: Sb. nauchn. Materialov Respublikanskoy nauchnoprakticheskoy konferentsii, 06 may 2014, Aktobe, KRMU. - Aktobe: Dizayn-studiya «Palitra», 2014. - 275 p.

9. Karabulatova IS (2005) Vvedenie v regional'nuyu etnolingvistiku. - MoscowTyumen': MPGU, "Prometey", 2005. - 200 p.

10. Karabulatova IS, Sayfulina FS, Akhmetova BZ (2013) Ethno-Lingual Aspect of Modern Functioning of Russian Dialects in North Kazakhstan (On an Example of Kostanai Region)// World Applied Sciences Journal 27 (Education, Law, Economics, Language and Communication): 137-140, 2013 ISSN 18184952 " IDOSI Publications, 2013 DOI: 10.5829/idosi.wasj.2013.27.elelc. 28 